特集 6 *

吐血・下血を主訴とした胃癌症例の検討

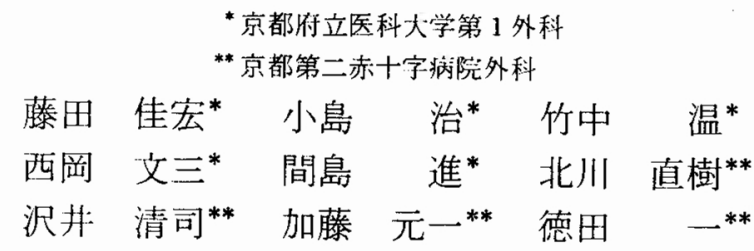

\title{
STUDY ON THE CASES OF GASTRIC CANCER WITH HEMATEMESIS AND MELENA
}

\section{Yoshihiro FUJITA, Osamu KOJIMA, Atsushi TAKENAKA, Bunzo NISHIOKA, Susumu MAJIMA, Naoki KITAGAWA* Seiji SAWAI, Motokazu KATOH* ${ }^{*}$ and Hajime TOKUDA*}

The First Department of Surgery, Kyoto Prefectural

* University of Medicine and Kyoto Daini Red Cross Hospital

索引用語 上部消化管出血, 胃癌, 腫瘍血管

\section{I はじめに}

上部消化管出血をきたす矤患のうち，欧米に沶いては 胃癌は比較的少数とされているが, 本邦に乱いては胃癌 の発生率が高いため, 胃癌は消化性潰瘍についで多い疾 患となっている. 胃癌の出血は, 穿孔・消化管狭窄など 胃癌の合併症として比較的高頻度で発生し, また, 一般 に末期癌に発生するとされているが，必ずしもそうでは なく，早期癌の初発症状として起こることもある.

今回, 過去 10 年間, われわれの教室および関連病院で 経験した，吐・下血を主訴とした胃癌症例103例を胃癌 顕性出血例として,この病態の特徵掞よび治療成績につ いて検討し, 若干の考察を加えた.

\section{II 検索対象}

昭和 43 年より 52 年までの 10 年間に, 教室拉よび関連病 院にて経験した上部消化管出血例は409例であり，との 内訳は表 1 のごとくである. 胃癌は103例で25.3\%を占 め，胃潰痬に次いで多く，㐬た同時期に経験した胃癌 1,144例の $9 \%$ に相当している.この103例を対象に, 入

* 第12回日消外総会シンポジウムII. 上部消化管出血
表 1 上部消化管出血の内訳 ( S 43. 1 52. 12)

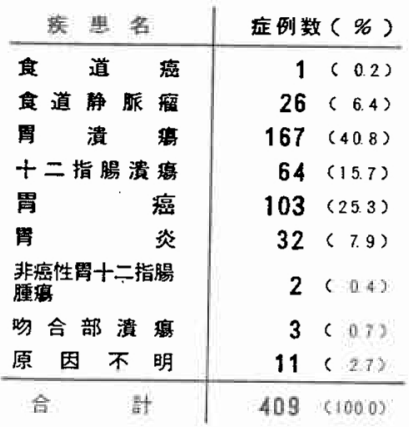

院時所見 - 年齢性別頻度 - 癌進行度 - 癌腫占居部位 - 肉 眼分類・腫瘍の拡がり・深達度・組織学的所見ならびに 腫演血管との関俰, さらに治療成績について胃癌研究会 規約1)に基づいて検索した。

\section{III 検索結果}

\section{1. 性別および年令別頻度}

性別についてみると, 男70例（68\%）に対して女33例 （32\%）で，男性に多くみられた。

年齢別頻度は, 図 1 亿示すごとく, 各年代ともに男性 が多かった，対象として昭和47年度全国胃癌登録 ${ }^{2} に よ$ 
図 1 胃癌顕性出血例の年令. 性別分布

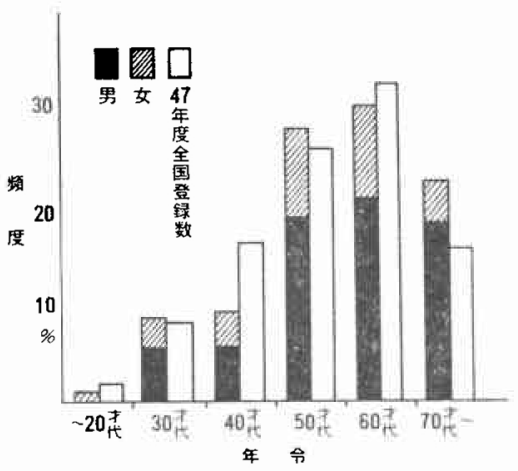

る年齢別の胃癌の発生頻度をとり，これと対比してみる と, 胃癌顕性出血例の年龄分布は，汪湆癌の発生分布 と類似しているが，50歳以上の高齢者にやや多い傾向を 示していた。

\section{2. 輗性出血の既往および程度}

顕珄出血の既往のあるものは103例中17例と比較的少 数で, 大部分が初回出血例であった，また，入院時顕性、 出血症状として，吐血・下欰をそれぞれ単独で訴えたる のはともに48例 (46.6\%) であり，吐・下血を訴えたる のは 7 例 $(6.8 \%)$ であった.

入院時の出血の程度を，(1）入院直前に 1 回の吐血 またはテール便を訴え，入院時24時間以内には無症状で あり，血液所見扣よび理学的所見に変化のないるのを (出血量 $100 \mathrm{ml}$ 程度と推定されたるの) 軽量群, (2) 入院後数回の吐血・下血があったが輸血 200〜600ccで 循環動態に変化なく，また血液所見として Ht 值が入 院初回検查値の $70 \%$ 以下にならなかったものを（出血 量200〜 500ml 程度と推定されたもの）中等量群，（3）

入院前より频回の吐・下血をくり返し，臨床所見では shock または, shcock 準備状態にあり，最大血圧が平 常時の30\%以上の低下を認め，血液所見で Ht 値が入 院初回検查の70\%以下に低下して, 輸晌量も1,000cc 以 上を要したものを(出折魱 $1,000 \mathrm{ml}$ 以上と推定された あの)大量群として, 以上 3 群に分けてみると, 検索 103例に打訬出の程度は軽量群38例 (36.9\%) -中 等量26例 $(25.2 \%) \cdot 大$ 量群39例 $(37.9 \%)$ と注 3 群 に 3 等分されていた.

\section{3. 癌進行度別分布}

検索103例の癌進行度は Stage I 22例 (21.4\%) - Stage II 23 例 $(22.3 \%) \cdot$ Stage II 15例 $(14.6 \%) \cdot$ Stage IV 33 例 $(32.0 \%) ・$ 不明10例 $(9.7 \%)$ で, Stage IVが最も
多く，したがって未期に出血しやすいことが想像された が, Stage I が21.4\%すあり，しかもこれらでは大量出 血例が過半数を占めたことが浩目された.

\section{4. 腫癔の占居部位}

癌腫の中心部の占める胃の部位を A・M・C に大別 乙て検索103例の 腫瘍占居部位を分類すると，A が43例 (41.7\%), Mが42例 (40.8\%) と注注同じ割合で多く C が15例 $(14.6 \%)$ と比較的少数であった. これらの割合 を47年胃がん全国登録による占居部位別頻度（C：13.8 $\% \cdot \mathrm{M} 38.0 \% \cdot \mathrm{A} 44.2 \%)$ と比較してみると, ほぼ同じ 分布を示しており，とくに出血例の占居部位による特徴 はなかった。

\section{5. 缰演肉眼分類との関係}

腫湯の肉眼型と出血との関係は表 2 のごとくで，亚型 が48例で約半数近くを占め，ついで I 型の20例，潰瘍形 成型が大半を占めているが，0型すなわち早期癌が13例 みられたことが注目された。これらは全てII c+III型を 示していた.

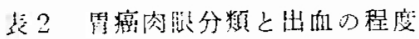

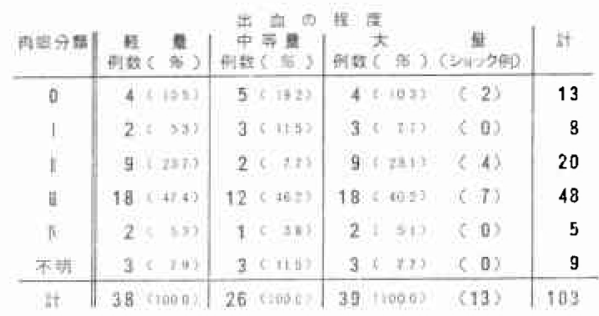

荠 3 腫瘍の大きさと出血の程度

\begin{tabular}{|c|c|c|c|c|c|c|}
\hline 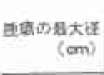 & 列数 & $\left(\begin{array}{l}\text { 量 } \\
\%)\end{array}\right.$ & 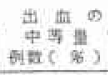 & 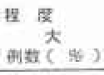 & $\underset{\left(\sum=/ 2 \theta i\right)}{\mathrm{R}}$ & $2 \pi$ \\
\hline$\sim 2$ क्ता & 2 & ( 533$)$ & $2(77)$ & $1(2.6)$ & ( 1) & 5 \\
\hline 2 -5 未政 & 12 & $(31.6)$ & $6(231)$ & $17(43.6)$ & (9) & 35 \\
\hline 5 - 10 末 & 14 & $8)$ & $17(654)$ & $g(23.1)$ & $(0)$ & 40 \\
\hline $10-$ & 5 & $(132)$ & $1(38.5)$ & $4(10.3)$ & $(2$ & 10 \\
\hline 不明 & 5 & 1322 & $0(0.0)$ & $8(20.5)$ & (1) & 13 \\
\hline 4 & 38 & one & 25 ก1:0 0 & $39(1600)$ & $\langle 13\rangle$ & 103 \\
\hline
\end{tabular}

また，沽㑑の程度に分けてみると，各群とも全体の割 合とほほ同じで, 各型とも顕著な特徵ではなかった。

\section{6. 澏诓の拡がりと出血の程度}

出血の程度と癌畽の拡がりとの関係をみるため, 畽瘍 の最大径 (肉眼) を, $2 \mathrm{~cm}$ 末満, $2 \mathrm{~cm} \sim 5 \mathrm{~cm}$ 末満, 5 $\mathrm{cm} \sim 10 \mathrm{~cm}$ 末満, $10 \mathrm{~cm}$ 以上の 4 群に分けてその例数を みると, 表 3 のごとくである. 5 10cm 未満のるのが 40例と最も多く, ついで $2 \sim 5 \mathrm{~cm}$ 末満のものが 35 例で, 
$2 \sim 10 \mathrm{~cm}$ 末満のものが大半を占めていた. この腫演の 大きさ別の発生頻度を 47 年度全国がん登録のそれと対比 すると，後者に拈ける発生率を上まわる割合を示したも のは $2 \sim 5 \mathrm{~cm}$ 未满のもので，しかもこの群では大量出芼 例が17例 $43.6 \%$ と最も多く，またショック症状を呈した 6の13例のらら9例がこの群に見られたことが注目され た. したがって，この $2 \mathrm{~cm} 〜 5 \mathrm{~cm}$ 未浾のものが出血の頻 度が高く，また大量出血をきたしやすいとい方る。

\section{7. 腫瘦の深達度と出血}

癌腫の深達度を胃癌研究会規約にしたがって， $\mathrm{m}$ 〜 $\mathrm{sm} \cdot \mathrm{pm} \sim \mathrm{ss} \cdot \mathrm{se} \sim \mathrm{si}$ の 3 群に分類すると，表 4 のごと くである. m〜sm が15例，pm〜ss が29例， se-si が47 例と深達度にしたがって出血例は多くなる傾向を示して いた.この傾向は出血の程度別にみてもほ注同様であっ た.

表 4 深橽度之出血の程度

\begin{tabular}{|c|c|c|c|c|c|c|}
\hline 宓遇基 & $\begin{array}{c}\text { 虽虽 } \\
\text { 列数( 复 }\end{array}$ & $\begin{array}{c}\text { 出血の } \\
\text { 中等量 } \\
\text { 列数( \%) }\end{array}$ & $\begin{array}{l}\text { 程 } \\
\text { 例数 }\end{array}$ & $\begin{array}{l}\text { 度 } \\
\text { 大 } \\
(\%)\end{array}$ & 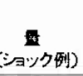 & at \\
\hline$m-s m$ & $4(10.5)$ & $6(23.1)$ & 5 & $(128)$ & $(2)$ & 15 \\
\hline$p m=s$ & $12(31.6)$ & $6(23.1)$ & 11 & $(28.2)$ & $(4)$ & 29 \\
\hline$a e-3 i$ & $18(47.4)$ & $12(46.2)$ & 17 & $(43.6)$ & $(5)$ & 47 \\
\hline 矛明 & $4(10.5)$ & $2(7.7)$ & 6 & $(15.4)$ & $(1)$ & 12 \\
\hline it & $38(1600) \mid$ & $28(1000)$ & 39 & (1000) & (13) & 103 \\
\hline
\end{tabular}

荠 5 露間質量々出血の程度

\begin{tabular}{|c|c|c|c|c|c|c|c|c|}
\hline 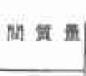 & 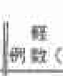 & $\begin{array}{l}\text { 量 } \\
\text { (5) }\end{array}$ & $\begin{array}{r}\text { 出 } \\
\text { 中 } \\
901\end{array}$ & 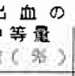 & 程 & (大 & ) (盟 & 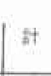 \\
\hline 晒标 & 146 & $(36.8)$ & 8 & $\langle 308\rangle$ & 17 & $(43.6)$ & ( 6$)$ & 39 \\
\hline 中成些 & 86 & $(21.1)$ & 4 & $(15.4)$ & 11 & $(282)$ & (4) & 23 \\
\hline 理泩些 & 86 & $(21.1)$ & 11 & $(42.3)$ & 6 & $(15.4)$ & ( 3 ) & 25 \\
\hline 㫜 & 86 & (21.1) & 3 & $(11.5)$ & 5 & $(128)$ & $(0)$ & 16 \\
\hline it & 138 & cuane? & 26 & cariogs & 39 & $\{100 \pi)$ & (13) & 103 \\
\hline
\end{tabular}

\section{8. 腫癁の病理組学的性状}

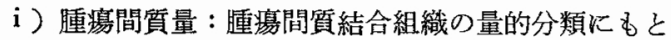
つきき, 検索対象例を髄様型・中間型・硬性型の3群に分 類すると表 5 のごとくである，髄様型は39例（38\%),中 間型は23例 $(22 \%)$, 硬性型25例 $(24.3 \%$, 硬性型に比 して䯣様型が多く，出血の程度に分けてみると，大量出 血例で髄様型17例 (44\%), 硬性型 6 例 (15\%) とその羑 はさらに大きくなる傾向を示した. したがって䯣様型に 出血の傾向がやや多いといえる.

ii) 腫瘍の組織型：検索例に扣ける胃癌研究会規約 による各組織型の頻度は, 表6のごとくである. poorly differentiated adenocarcinoma が33例と最も多くなって
表 6 胃癌顕性出血例の組織型

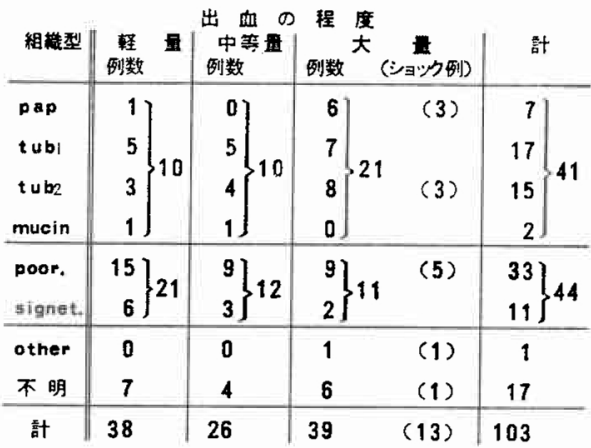

いるが，分化型と低分化型とに大別して比較すると，そ の割合はほぼ同率であった．しかし大量出血例において 分化型が約 $2 / 3$ 占めて拉り，分化型が大量出血をきた しやすいと云える.

\section{9. 腫瘍血管について}

検索症例103例のらちで組織学的に検索可能な症例に ついて, 腫瘍血管の状態を潰瘍底・畽瘍内 - 畽瘍周辺に わけて検索し，血管の露出・増生・払張などの程度を総 合して士，十，\#，卅の 4 段階に分類し， H以上を示す 症例の頻度と前述の検討で出血と相関を示した深達度と 腫瘍間質量との関係を検討した。

i ）腫瘍血管と深達度との関係：表 $7 \mathbf{a}$ に示すごと く, 深達度 pm 以上では深達度が增寸につれて, 腫瘍 血管の増生・拡張などの著明な症例が多くなる傾向を示 したが，sm 以下の早期癌に括いては溃瘍底血管露出お。 よび腫瘍周辺の 血管増生が 著明であることが注目され た

表 $7 \mathrm{a}$ 深達度と腫煌血管との関係

\begin{tabular}{|c|c|c|c|c|c|c|}
\hline स噇症 (6) & 量琶 & 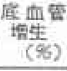 & 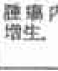 & 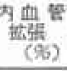 & 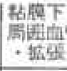 & 16) \\
\hline$m-\operatorname{sm}(13)$ & 7 & $(538)$ & 5 & (5) 5) & 12 & $(925)$ \\
\hline pen s s (19) & 2 & $(105)$ & 7 & $(36: 8)$ & 10 & $(52.6)$ \\
\hline (26) & 4 & $(154)$ & 15 & $(477)$ & 18 & $(692)$ \\
\hline
\end{tabular}

表 $7 \mathrm{~b}$ 間質量と尰場血管との関係

\begin{tabular}{|c|c|c|c|c|c|}
\hline \multicolumn{2}{|c|}{ 間 } & 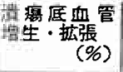 & 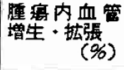 & 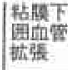 & 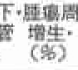 \\
\hline 轋 & 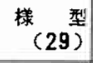 & $\begin{array}{ll}8 & \\
& (27.6)\end{array}$ & 16 (55.2) & 21 & $(72.4)$ \\
\hline 㛏 & $\begin{array}{c}\text { 性 } \quad \text { 型 } \\
(16)\end{array}$ & $\begin{array}{ll}2 & \\
& (12.5)\end{array}$ & $5_{\text {(31. } 3)}$ & 9 & $(56.3)$ \\
\hline
\end{tabular}


i ）腫㾤血管と間質星との関係 : 髅様型29例扣よび硬 性型16例について, 腫瘍血管の状態を比較してみると, 表 7b のごとく，髄様型の腫瘍血管の増生・拡張など が, 硬性型のそれらに比して著明な症例が多くなってい た.

\section{0. 検索例の治㞠成績}

胃癌顕性出血例103例のらち，手術例は92例（祭急手 術10例, 待期手術82例) であり, 非手術例は11例であっ た. 手術例の手術々式・術後合併症・手術死亡（1 力月 以内死亡）などの手術成績の内訳は，表８のごとくであ

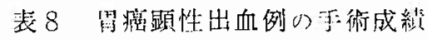

\begin{tabular}{|c|c|c|c|c|c|c|c|c|c|c|}
\hline & $\begin{array}{c}\text { 緊 } \\
\text { 列数 }\end{array}$ & 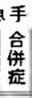 & 溥 & 待政 & $\begin{array}{l}\text { 苸 } \\
\text { 盒 } \\
\end{array}$ & 毒画 & $\begin{array}{l}\text { 手 } \\
\text { 列数 }\end{array}$ & $\begin{array}{l}\text { 例合 } \\
\text { 盒 } \\
\text { 咅 }\end{array}$ & \\
\hline & 全 & 1 & 0 & 0 & 11 & 1 & 0 & 12 & 1 & 0 \\
\hline & 磧門荝 & 1 & 0 & 0 & 8 & 1 & 0 & 9 & 1 & 0 \\
\hline & 幽門例 & 3 & 3 & 2 & 58 & 9 & 3 & 61 & 12 & 5 \\
\hline 菲 & 単閐腰 & 3 & 2 & 2 & 2 & 0 & 0 & 5 & 2 & 2 \\
\hline 除 & 物 合 & 2 & 1 & 1 & 3 & 1 & 1 & 5 & 2 & 2 \\
\hline 合 & 討 & 10 & 6 & 5 & 82 & 12 & 4 & 92 & 18 & 9 \\
\hline
\end{tabular}

る. 切除例は92例中82例 $(89 \%)$ で，全剔12例・噴門側 9 例・幽門側61例であった．非切除例は10例で，単閉腹

・胃腸吻合それぞれ 5 例であった。

術後合併症は92例中18例 (19.6\%), 手術死亡例は 9 例 で手術死亡率は $9.8 \%$ と一般の 胃癌切除に 比し高率であ った. 緊急手術例（入院後24時間以内）と待期手術例に 分けると，前者は10例で，そのらち術後合併症は6 例 $(60 \%)$, 手術死亡率は 5 例 $(50 \%)$, きわめて手術成 績が悪かった。一方, 待期手術例は82例で, その術後合 併症は12例 $(14.6 \%)$, 手術死亡は 4 例 $(4.9 \%)$ で，緊 急手術例に比較して良好であった。

緊急手術例10例のうち8例は入院時ショック症状を呈 したものであり，また 3 例を除いた他は全て Stage IV の末期癌症例であった. 術式についてみると, 切除 5 例

- 胃腸吻合 2 例・胃切開止血 3 例であり，手術死亡は心 不全，肺炎，偽膜性腸炎の各 1 例づつと術後出血 2 例で あった。

\section{IV 考 察}

上部消化管出血をきたす疾患は，古今東西を間わず， 胃十二指腸潰瘍が最も多く, 次いで欧米では食道静脈瘤 であり，胃癌はきわめて少なく Bocus ${ }^{3)}$ によると1.4〜 2.7\%を占めるに過ぎない，しかし，本邦に抹いては胃 癌の発生頻度が高率であるため，その占める割合も胃潰
瘍についで多く，12.1 22\%(4) 9) と報告されている，今 回の集計でも吐・下衈を主訴とした上部消化管出血例の らち胃癌は $25.3 \%$ とや高率を占めた．胃癌の約 $70 \%$ は 主として潜出血を示しているが，顕出卹をきたす割合 は，暒谷ら゙にによれば27.8\%，木本らによれば23.5\%，

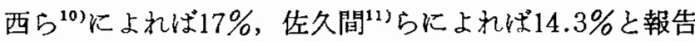
されており，今回の検索では検索期間の罥癌全症例の 9 \%でありこれらに比してやや低率であった.しかし，

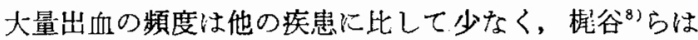
$1.1 \%$, 武藤 ${ }^{12}$ は0.7\%, 岡島 ${ }^{13}$ は1.7\% と報告しており， 藷者らの criteria で大量出血例としたものは39例で，全 症例の3.4\%とやや高率を゙示した。しかし，胃癌の出血 量の推定は出血が持続性であるといら特徵から困難で, 徐々に貧血・脱水などのショック準備状態におかれてい る場合が大半と考元られ，したがって，ショック症状を 呈したものを大量出血例としても，他の疾患のいわゆる 大量出血之同程度のものはきわぬて少数であろらと思わ れる. 胃癌顕性出血例でショック症状を呈したものの頻 度については，木本ら”は26\%，小林 ${ }^{14} ら は 15 \%$ 認め たと述べているが，著者らの経験した胃癌のショック例 は顕性出血例103例中13例 $(12.6 \%)$ であり, 教室例に 去ける食道静脈瘤26例中12例 (46\%), 胃潰瘍167例中38 例 $(22.8 \%)$ のた比して低率であった。

年路・性別頻度，腫瘍の占居部位については，47年度 全国胃癌登録による各々の発生頻度と対比してみると, 今回の集計のそれときわめてよく相関しており，したが って顕出血例に特徴は見い出し得なかった。

胃癌の進展との関係は，一般に進行度が增すにつれて 出血例が多くなるといわれているが，著者らの stage 別 頻度ではIV・II・I・II の順で, 進行度とははっきりし た相関は示さなかったが，深達度とはよく相関すること から考觉ると, やはり進行す机ば顕性出血の頻度が高く なることは充分想像される。

肉眼的癌型については，正型が48例，II 型が20例之， 従来の報告 ${ }^{8) 16)}$ と同様，潰瘍形成型が大半を占めたが， 0 型すなわち早期癌が13例 $(12.6 \%$ ) に見られたことが 予想外であった．顕性出血骨癌のらち早期癌の占める割 合については，西ら $\left.{ }^{10}\right)$ 怕例中 2 例 $(6 \%)$,佐久間 ${ }^{11)} 5$ は203例中20例 $(9.9 \%)$ と報告しており, 佐藤ら $\left.{ }^{15}\right)$ は早 期癌症例のうち顕出血をみたものが7.6\%あったと述べ ているところから, 出血が早期癌の初発症状になること を示している．著者らの13例は全てII $\mathrm{c}+\mathbb{I I}$ を呈して括 り,このらちには胃潰瘍と術前診断されたすのが 3 例含 
まれていたことが注目された。

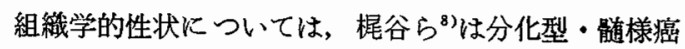
に出血例が多いと述べているが，著者らの検索でも硬性 型に比して䯣様型にその頻度が多く, 組織型では低分化 型と分化型との間には差はなかったが，大量出血例の大 半は分化型で占められていた.

これら胃癌出血に密接な関係をるつ進展の程度掞よび 組織学的な特徵として, 著者らの検索結果からも腫瘍血 管の状態とある程度の関係があると考えられる，胃癌の 血管構築に関しては多くの研究がなされているが ${ }^{16) ~ 199, ~}$ 中西 $5^{18)}$ は早期胃癌病変部に一致して粘膜下血管網扎よ び粘膜血管の蛇行が著明となり，周辺部に比して血管分 布が密であると述べており，われわれの早期癌または早 期癌類似進行癌の顕性出血例でしばしば認めた所見とよ く一致し，またこれらの潰瘍底には明らかに出血源であ ったと思われる比較的太い血管端の露出がしばしば認め られた。潰瘍形成型は一般に癌腫の中心部は hypovascular で，周辺は hypervascular であるといわれこと に分化型ではこの傾向が強いといわれている. これは癌 腫が増大すると中心壊死をきたしやすく，さらに進んで 周辺の血管の破綻が起こりやすいと考えられる. また， 丸山ら ${ }^{19}$ は，これらの潰瑒面に形成された肉芽層には非 常に太くて短い血管がブラシように密に配列した定型的 な肉芽血管が認められると述べて挌り，これらは胃癌の 出血汇関係する重要な所見であると思われる.

胃癌䫓性出血例の治療成績についてみると，木本ら" は, 胃癌出血緊急入院例 20例中手術例は18例で，その らち手術死亡例の 4 例 $(22.2 \%)$ をみて特り, 村上 ${ }^{20}$ ら は手術例13例中 3 例（23\%）の死亡例を報告している.

著者らの手術成績でる 手術例 92 例中 9 例 $(9.8 \%)$ の手 術死亡を認め，ことに緊急手術例は 10 例中 5 例と半数を 失って和り，一般の胃癌成績に比してきわめて悪い。こ れは，前述のごとく胃癌出血例にはかなり進行したもの が多く, 大量出血でさらに全身状態を極度に悪化させ, その上でのこの時期の手術が患者にとってきわめて過大 侵襲になったためと考兄られる．したがって胃癌の出血 と判明した場合はできるだけ待期の姿勢で臨むべきであ ろらが，われわれの緊急手術例の大半が，ショック症状 を呈し，止血が望まれずやむなく祭急手術になった症例 であり、こらした場合実際には手術時期の決定はきわめ て困難である。しかし，やむを得ず緊急手術になった場 合は, 患者の Risk を充分考虑の上, poor risk の場合 は止血を第 1 の目的として，侵襲を最小限にとどめる術
式が選ばれるべきと考える.

今 1 つは, 胃癌顕性出血例の術前診断が, 胃潰煌等の 良性疾患として切除術がなされ，非治痹切除になること である. 村上ら ${ }^{201}$ は21例中 2 例, 管野ら ${ }^{21}$ は35例中 9 例 を報告して怙り，われわれの103例中12例が胃潰瑒とし て手術がなされている。これ関しては大いに反省すべ きであり，祭急内視鏡の手技が進歩した現在に捻いて は，上部消化管出血例に対しては積極的にこれを施行し て, 術前に病変部の把握につとめ, 手術に臨んでる潰瘍 縁の疑わしい部分は必す涷結迅速切片による組織学的検 索がなされるべきであることを強調したい，

\section{$\mathbf{V}$ 結 語}

過去10年間，教室际よび関連病院で経験した吐・下血 を主訴とした上部消化管出血例409例のうち胃癌103例を 対象として, 胃癌頭性出血例の病態の特徵㧍よび治療成 績について検討し, 次の結果が得られた.

1.上部消化管出血例のうち胃癌は $25.3 \%$ をめ, ま た, 胃癌全症例の $9 \%$ に相当した。

2. 性別・年龄別 - 腫湟占居部位別の頻度は, 一般の 胃癌発生頻度分布と類似し, 特幑はみられなかった。

3. 進行度とははっきりした相関は認めなかったが， Stage IVが最も多く, ことに顕性出血例頻度と深達度 との間には，はっきりした相関が認められた。また，早 期癌が13例 (12.6\%) 認められたことが注目された。

4. 病理組織学的性状については, 肉眼型では正型 ・ II 型の潰瘍形成型が大半をしめ, 組織型では分化型飞大 量出血例が多く，腫瘍間質量では檤様型汇多く認められ た. また，出血には腫瘍血管の性態が関係していること が推察された。

5. 治療成績は103例中手術例は92例であり，術後合 併症は 18 例 (19.6\%), 手術死亡例は 9 例 $(9.8 \%)$ と一 般の胃癌手術成績に比して悪く，ことに緊急手術例10例 中 5 例 $(50 \%)$ が手術死亡して拉り, 待期手術82例中 4 例 $(4.9 \%)$ に比べてきわめて悪い成續であった．した がって, 胃癌顕性出血例に対してはでさるだけ待期の姿 勢で臨むべきものと考劣る.

\section{文献}

1) 肢胃癌取报い規約 (第 9 版)，胃癌研究会編，金 原出肘, 東京。

2）全国胃がん登録調査報告（第 8 号)，昭和 47 年 度症例，胃がん研究会，国立がんセンタ一。

3) Bocus, H.L., Gastroenterology, 3rd edition, chapter 32, Hematemesis and Melena Part 1, 763-826, W.B. Sanders company. Philadel- 
phia. London Tronto, 1974.

4) 梶谷良男他 : 大量胃出血, 外科治療, 5:129 143，1961.

5) 山形敬一他：出血をきたす小腸疾患とその対 策；診療，16:1260～1269, 1963.

6)梅原千治他：吐血およ下血の䠛床的並に統計的 観察; 消化器病 の臨床, 6(9): 708〜 719, 1964.

7) 長尾房大他：胃出血患者の病態と集計的皤察. 外科, $30: 453 \sim 461,1969$.

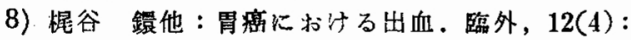
$233 \sim 242,1957$.

9) 木本誠二他：外科領域における吐血と下血，61 (6) : 354 357, 1964.

10) 西 满正他：上部消化管大量出血の手術をめぐ る問題点一胃癌一。臨外, 32 (8): 999 1004, 1977.

11) 佐久間晃他：胃癌からの大量出血の治療, 外 科治療, $28(6) ： 674 \sim 680,1973$.

12）武藤完蜼：外科からみた胃癌, 金原出版, 1963.
13）岡島邦雄 : 胃癌出血, 外科, 39 (11)：1233 $1246,1977$.

14）小林迪夫他：上部消化管出血における出血源の 臨床特性, 臨外, 27 (9): 1251 1256, 1972 .

15）佐藤寿雄他：胃癌の出血，外科診療，14:397 $404,1972$.

16) Thinesse, N.W.: The vascularity of benign and malignant lesion of the stomach, S.G.O., 63: 149-156, 1936.

17) 上垣恵二他：消化管の徽少循環, 医学のあゆ み, 57 (5)： 332 340, 1966.

18）中西宏行：切除胃壁に分布する血管の究研，日 外会誌, 72 (11) : 1682 1710, 1971 .

19）丸山圭一他：胃癌の微細血管構築一血管像によ る胃癌の分類と血行転移に関する研究, 日外会 誌, $73: 1260 \sim 1262,1972$.

20) 村上忠重他: 上部消化管出血の統計的観察, 外 科, 28 (6): 556 563, 1966.

21）菅野久義他：癌患者に求汁る急性消化管大量出 血例い検剖，外科，35（5）:520 524， 1972. 